\title{
DESPRENDIMIENTO SEROSO DE MÁCULA COMO MANIFESTACIÓN ATÍPICA EN LA ENFERMEDAD DEL ARAÑAZO DEL GATO
}

\section{SEROUS MACULAR DETACHMENT AS AN ATYPICAL SIGN IN CAT SCRATCH DISEASE}

\author{
ASENSIO-SÁNCHEZ VM ${ }^{1}$, RODRÍGUEZ-DELGADO B ${ }^{2}$, GARCÍA-HERRERO E², \\ CABO-VAQUERA V ${ }^{2}$, GARCÍA-LOYGORRI C ${ }^{1}$
}

\section{RESUMEN}

Caso clínico: Paciente de 58 años con una agudeza visual de 0,1 en el ojo izquierdo asociada a un desprendimiento seroso de la mácula como única manifestación ocular de la enfermedad del arañazo del gato. El diagnóstico se realizó con estudios serológicos y por la evolución clínica.

Discusión: Aunque es poco frecuente, la enfermedad del arañazo del gato debería considerarse en el diagnóstico diferencial del desprendimiento seroso de mácula.

Palabras clave: Enfermedad por arañazo de gato, Bartonella henselae, desprendimiento seroso de mácula, eritema nodoso, linfadenopatía.

\begin{abstract}
Case report: A 58-year-old woman presented with 0.1 visual acuity in the left eye associated with a serous retinal detachment of the macula as the only ocular manifestation of cat scratch disease. This diagnosis was made by serum antibody titers and the clinical course.

Discussion: Although uncommon, cat scratch disease should be considered in patients with a serous detachment in the macula region of the retina (Arch Soc Esp Oftalmol 2006; 81: 717-720).

Key words: Cat scratch disease, Bartonella henselae, serous detachment in the macula, erythema nodosum, lymphadenopathy.

riormente Rochalimaea) henselae que es un bacilo pleomórfico gram negativo $(1,2)$. El gato es el huésped natural de Bartonella henselae siendo los gatitos (menores de 1 año) el mayor riesgo para la transmisión de la enfermedad aunque se desconoce si es por una mayor frecuencia de la infección en los
\end{abstract}

Recibido: 6/3/06. Aceptado: 21/11/06

Hospital General. Medina del Campo. Valladolid. España.

1 Doctor en Medicina.

2 Licenciado en Medicina.

Correspondencia:

V.M. Asensio Sánchez

Hospital General Servicio Castellano-Leonés de Salud

Servicio de Oftalmología

Medina del Campo (Valladolid)

España

E-mail: vasensio@hmdc.sacyl.es 
gatitos o simplemente refleja la tendencia de éstos a morder y arañar en actividades de juego $(1,2)$. Se describe un caso clínico de presentación atípica de enfermedad por arañazo de gato.

\section{CASO CLÍNICO}

Paciente de 58 años sin antecedentes familiares de interés y con antecedentes personales de hipertensión arterial controlada farmacológicamente durante 6 años y sinusitis maxilar de 10 días de evolución sin tratamiento específico. Acude a urgencias por «pérdida y distorsión de la visión» en el ojo izquierdo (OI) de varios días de evolución. La agudeza visual máxima en el ojo derecho (OD) era de 1 y en el OI de 0,125 , la motilidad ocular extrínseca e intrínseca fueron normales, el estudio con lámpara de hendidura no presentaba patología. La exploración fundoscópica en el OD fue normal pero en el OI había un desprendimiento seroso macular que se extendía hasta los vasos temporales superiores e inferiores (fig. 1), el nervio óptico y el resto del parénquima retiniano no presentaban alteraciones. Refiere el arañazo de un gato en el muslo de la pierna izquierda dos semanas antes de la pérdida de visión (fig. 2). Siete días después de ser explorada por nosotros, desarrolló unas lesiones eritematosas

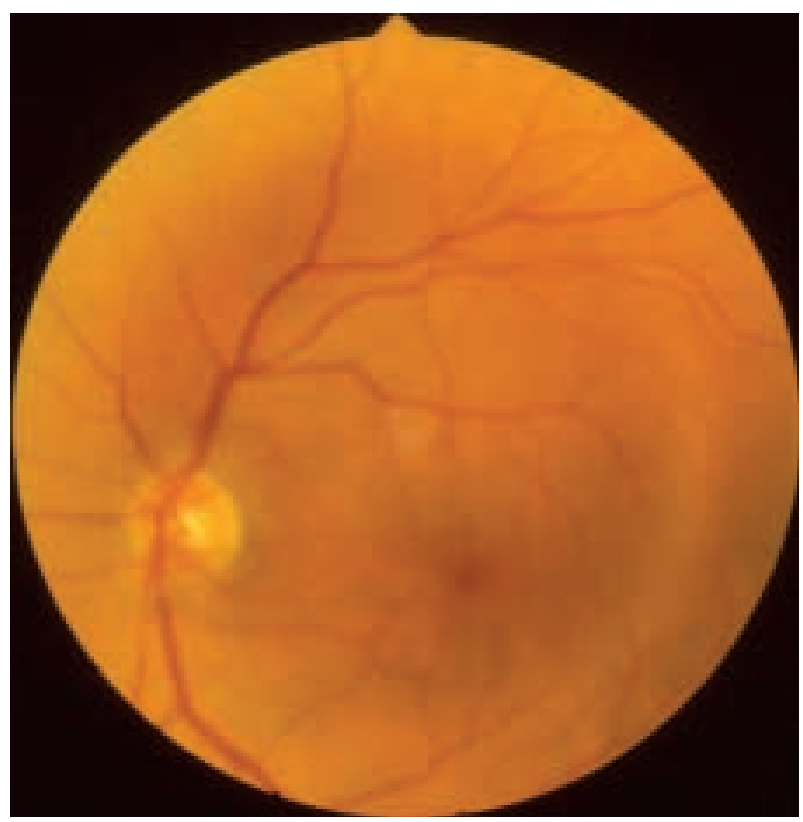

Fig. 1: Desprendimiento seroso macular de 2 semanas de evolución. Obsérvese que el nervio óptico es normal.

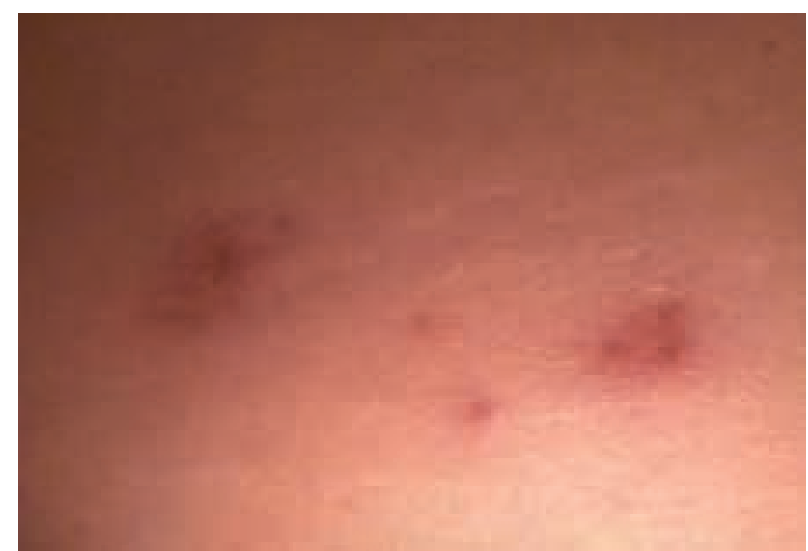

Fig. 2: Puerta de entrada de Bartonella henselae. Aspecto eritematoso y sobreelevado de la lesión. A la palpación era una zona rígida y con adenopatías satélites.

dolorosas limitadas a las extremidades inferiores compatibles con eritema nodoso que en el plazo de 20-25 días se ulceraron (fig. 3). Se realizó interconsulta al servicio de medicina interna para estudio compartido. La radiografía de tórax fue normal, la radiografía de senos paranasales determinó un ligero velamiento en el seno maxilar izquierdo. Los estudios serológicos: ANA, ANCA, ac antifosfolípidos fueron normales. La serología CMV, VEB, Rickettsias, Toxoplasma, VIH, Lyme y la serología luética fueron negativas. El Mantoux también fue negativo. Hemograma: Leucocitos 20.670, VSG 64 $\mathrm{mm} \mathrm{1.}{ }^{a} \mathrm{~h}, \mathrm{PCR}$ 16,4 mg/L. Los niveles serológicos de IgM frente a B. Henselae por ELISA fueron positivos a un título de 1:812. La paciente fue tratada con ciprofloxacino 1 gramo al día durante 14 días. A las cuatro semanas del tratamiento el cuadro

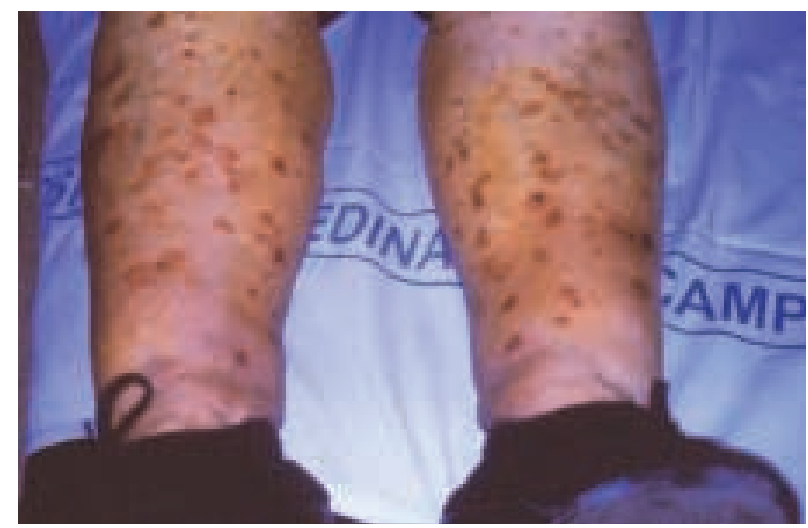

Fig. 3: Lesiones nodulares eritematosas localizadas en extremidades inferiores que presentan diferentes grados de evolución. 
sistémico empezó a regresar y el oftalmológico se resolvió alcanzando el OI una agudeza visual de la unidad.

\section{DISCUSIÓN}

La enfermedad por arañazo de gato es una enfermedad infecciosa rara producida por una bacteria del género Bartonella. Las formas más leves pueden pasar inadvertidas y resolverse sin tratamiento por lo que la incidencia de la enfermedad es difícil de establecer (1). Es la causa más frecuente de adenopatías crónicas en niños y adultos jóvenes tras el contacto con gatos o menos frecuentemente con perros. La fuente de la infección es un rasguño, mordedura, o lametazo de un gato. La Bartonella Henselae, responsable de la enfermedad, se encuentra en todas las partes del mundo; más del $60 \%$ de los casos se producen en niños (1), siendo frecuente la aparición de múltiples casos en una misma familia, especialmente entre las que tienen algún gato y sobre todo en los meses calurosos (1). Tiene un período de incubación que va desde varios días a varias semanas, desarrollándose adenopatías regionales acompañadas o no de un cuadro pseudogripal con fatiga y fiebre que normalmente es autolimitado pero en situaciones inusuales puede progresar a una enfermedad sistémica severa (hepato-esplenomegalia, hepatitis granulomatosa, osteomielitis, encefalitis y neumonía) o recurrente (1). La afectación ocular se produce en un $10 \%$ de casos, siendo las más comunes el síndrome oculoglandular de Parinaud, la retinocoroiditis y la neurorretinitis. El desprendimiento seroso de mácula como única manifestación de esta enfermedad ha sido publicado en escasas ocasiones $(3,4)$. La paciente que se describe presentó una lesión eritematoso-papular en el sitio de la inoculación, seguida por una reacción sistémica inusual en extremidades inferiores en las tres semanas siguientes que no hemos encontrado descrita en ninguna base de datos bibliográficas consultadas y en éste contexto desarrolló a nivel ocular un desprendimiento seroso de mácula sin afectación del nervio óptico dos semanas después del arañazo de un gato infectado con Bartonella henselae. La aparición del cuadro oftalmológico previo a la sintomatología sistémica es un hallazgo inusual (3). Zacchei et al (4) describen una paciente con EAG y un desprendimiento seroso de mácula sin papilitis ni neuroretinitis. Solley W et al (3) en una serie de 35 ojos con clínica de EAG presen$\tan 7$ casos (20\%) con desprendimiento seroso, pero a diferencia de nuestro paciente, en todos los descritos por Solley et al (4) había inflamación vítrea. El diagnóstico se basa en los hallazgos clínicos, en la historia de exposición a gatos y en el test serológico positivo (1). Generalmente cura sin necesidad de tratamiento antibiótico, aunque la terapia antibiótica puede acelerar la recuperación.

\section{BIBLIOGRAFÍA}

1. Tompkins LS. Bartonella infections, including cat-scratch disease. In: Isselbacher KJ. Harrison's Principles of Internal Medicine. Nueva York: McGraw-Hill; 2002: 1003.

2. Ormerod LD, Dailey JP. Ocular manifestations of catscratch disease. Curr Opin Ophthalmol 1999; 10: 209216.

3. Zacchei AC, Newman NJ, Sternberg P. Serous retinal detachment of the macula associated with cat scratch disease. Am J Ophthalmol 1995; 120: 796-797.

4. Solley WA, Martin DF, Newman NJ, King R, Callanan $D G$, Zacchei $T$, et al. Cat scratch disease: posterior segment manifestations. Ophthalmology 1999; 106: 15461553. 